\title{
Monetary Seigniorage in an Emerging Economy: Empirical Evidences
}

\author{
Lekha Chakraborty ${ }^{1}$ \\ ${ }^{1}$ National Institute of Public Finance and Policy and Research Associate, Levy Economics Institute, New York \\ Correspondence: Lekha Chakraborty, Associate Professor, National Institute of Public Finance and Policy, 18/2 \\ Satsang Vihar Marg, Special Institutional Area, Near JNU East Gate, A-17 Aruna Asafali Marg, New Delhi \\ 110067, India. Tel: 011-2656-9303. E-mail: lekhachakraborty@gmail.com
}

Received: March 7, 2018

doi:10.5539/ijef.v10n5p135
Accepted: April 4, 2018

Online Published: April 10, 2018

\begin{abstract}
It is often emphasised that monetary seigniorage financing of public sector deficits is technically a "free lunch" if the economy has not attained the full employment levels. However, conservative macroeconomic policies in many emerging and developing economies, especially in the last two decades, have moved away from seigniorage financing to debt financing of deficits to give greater autonomy to the central banks. Against this backdrop, the paper analyses the fiscal and monetary policy co-ordination in India by constructing a monetary seigniorage Laffer curve. If such a curve exists, it is possible to derive a seigniorage-maximizing inflation rate to estimate the optimal level of seigniorage financing of deficits. The illustrative estimates from the Indian data using error correction mechanism models confirm the possibility of a monetary seigniorage Laffer curve.
\end{abstract}

Keywords: fiscal-monetary policy co-ordination, Seigniorage, fiscal deficits, error correction mechanism, Seigniorage laffer curve

\section{Introduction}

There is a growing concern about the tendency of segregating the monetary and fiscal policy while assessing the macroeconomic impact of deficits on economic growth outcomes. This paper attempts to revisit this dichotomy that prevails in the contemporary macro policy space and analyses the plausible linkages between the fiscal and monetary policy co-ordination, through constructing monetary seigniorage in the context of India.

The significance of institutional linkages between fiscal and monetary authorities can be traced back to 'Unpleasant Monetary Arithmetic' (UMA) of Sargent and Wallace (1981). The 'Unpleasant Monetary Arithmetic' revealed that fiscal policymaker (where fiscal authority has the 'first mover advantage, and the monetary policy follows) dominates in the financing decision of deficits. If the bond financing of deficits becomes sooner or later unsustainable, the Central Bank has to step in and generate the monetary seigniorage revenues to monetize the deficits eventually. Under this fiscal dominance hypothesis, the attempts by the central bank to keep inflation low through inflation targeting cannot last and must ultimately give into higher inflation in the longer run. Under UMA, inflation today or inflation tomorrow is the only plausible macro policy option and therefore it is referred to as the 'unpleasant monetarist arithmetic'.

Does the macroeconomic scenario of UMA better for growth outcomes rather than central bank independence? The situation of central bank independence and inflation targeting with no fiscal policy dominance is referred to as 'Unpleasant Fiscal Arithmetic' (UFA). The Unpleasant Fiscal Arithmetic thus visualizes to reverse the order of adjustment, assumed in UMA, and to transfer the first mover advantage from fiscal agencies to the Central Bank authorities. By introducing strict fiscal policy rules, it obliges fiscal agencies to adjust to the anti-inflationary policy of the independent Central Bank and thus Unpleasant Monetary Arithmetic turns into Unpleasant Fiscal Arithmetic (Winckler et al., 1998).

A recent treatment of the Sargent-Wallace argument of fiscal-monetary policy linkages is the "fiscal theory of the price level", (FTPL), pioneered by Leeper (1991), Sims (1994), Woodford (1994) and Cochrane (1998). This fiscalist literature argues that the price level is independent of monetary policy but dependent strictly on fiscal policy; price level indeterminacy problems can be solved by having the central bank peg the nominal interest rate at a level consistent with the central bank's desired inflation rate, rather than by controlling the growth rate of the (base) money supply (Sims, 1994; and Woodford, 1994).

These theoretical debates find relevance in contemporary macro policy transition in India from discretion to rules. 
The fiscal policy institutions have moved away from discretionary fiscal stance towards fiscal rules - the efficacy of fiscal authorities to keep the deficits within the numerical threshold level of deficits normalized to GDP (Andrea Schaechter et al., 2012). Recently, the monetary policy authorities have begun the policy rules to 'inflation targeting' and 'central bank independence' in India (for details, Urjit Patel Committee recommendations, Reserve Bank of India, 2014 and the 'new monetary framework', signed between Government of India and Reserve Bank of India, February 2015). This new dimension of the rule-based monetary policy stance in India has spurred from Taylor's rule (Taylor \& Williams, 2010).

The contemporary macroeconomic policy transition from discretion to rules gives rise to one pertinent question: does monetary rule require a fiscal rule? Such monetary-fiscal linkages are treated in the literature (for instance, Sargent \& Wallace, 1981) through analyzing the macroeconomic channels through which deficits affect monetary policy stance (Note 1). Unfortunately, over the years, the coordination between fiscal and monetary policy has been weakening and the policy debates have confined to just numeric values of deficits -the 'levels' of deficit to 3 percent of GDP- in attempting such linkages. Apparently there has been a widening acceptance that numeric Fiscal Rules are associated with greater fiscal discipline (Alesina \& Perotti, 1995).

Against this backdrop, the paper attempts to examine the theoretical and empirical linkages between fiscal and monetary policy. It presents an illustrative estimation of seigniorage and deficits linkages, through arriving at a plausible seigniorage Laffer curve.

The paper is organized into four sections. Section 2 explores the stylized facts relate to measuring deficits and financing pattern of deficits in India, with special reference to seigniorage financing. Section 3 deals with the estimation of monetary seigniorage. Using error correction mechanism models, an attempt to develop a threshold level of seigniorage maximizing inflation and plausibility of monetray Seigniorage Laffer curve would be attempted in section 4 , the estimation is preliminary and illustrative. Section 5 concludes and suggests policy options.

\section{Stylised Facts: Measuring Deficits and Seigniorage Financing}

As a prelude to estimating monetary seigniorage, it is pertinent to discuss the appropriate concept of public deficit, and the optimal financing patterns of the public deficit with special emphasis on seigniorage. This section deals with the measurement issues related to the public deficit; and in turn interprets data on the trends and financing patterns of public deficits in India.

It is argued that unless a correct indicator of deficit is adopted, there is a possibility of miscalculation of pre-emption of resources by the government and thus the assessment of the fiscal policy and its impact on macro economy (Boskin, 1988). This evolution towards a series of purpose-specific deficit measures worldwide, as a prelude to Fiscal Rules, from the conventional approach of single measure of budget deficit resulted in construction of primary deficit, fiscal deficit, monetized deficit and revenue deficit (for details, four pioneering surveys on the measurement of purpose-specific budgetary deficits by Blinder and Solow (1974), Heller et al. (1986), Blejer and Chu (1988) and Blejer and Cheasty (1993); and Pattnaik et al. (1999) for details on India-specific measurement issues of deficit).

As for the coverage, the ideal concept of deficit to study the macroeconomic impact is the Public Sector Borrowing Requirement (PSBR). In other words, ideally, any measurement of the deficit should consider the deficit of the public sector as a whole instead of a sectoral deficit of different public sector entities. But problem lies in covering the public sector as a whole for a comprehensive measurement of public sector deficit because there are more exhaustive lists of government entities and there are intra-public sector transactions for which data is not readily available. Unless, into a public sector transactions are netted out, estimation of public sector deficit may suffer from the problem of double counting leading to the overestimation of the deficit. Thus, any measurement of government deficit should be defined by a public sector of given coverage, the intersectoral linkage within the public sector has to be delineated and a time horizon should be specified to assess the impact of fiscal deficit (Blejer \& Cheasty, 1993).

Apart from the above-discussed Public Sector Borrowing Requirement (PSBR), various concepts of the deficit and their use as indicators to evaluate the budgetary performance of the government are recent phenomena in India. This evolution is also a result of the contemporaneous paradigm shift to a series of purpose-specific deficit measures worldwide, from the conventional approach of a single measure of the budget deficit.

The generation of purpose-specific deficits has the huge relevance of facilitating the analysis of the impacts of fiscal policy stance on macroeconomic activity. However, the formulation of numerical bound and fiscal rules has shrunk the possibility of maturing such debates of macroeconomic impacts of fiscal stance, and the debates 
have confined to the numerical fiscal rules.

Traditionally (up to the late '80s), the concept of the budget deficit was in prominence in India and containing of the budget deficit was the prime objective of fiscal management. Budget deficit or the overall deficit of the central government is that part of the deficit that was covered by 91 days Treasury bills and withdrawal of cash balances with RBI. As the budget deficit is the borrowing from the central bank, it increases reserve money into the system and could fuel inflation and destabilize the monetary system. Thus, the emphasis was given to reduce the volume of the budget deficit. As RBI holds dated government securities, which also increases the volume of reserve money into the system, the budget deficit could only give a partial picture of the total increase in the reserve money. To capture the exact impact of deficits in the creation of reserve money, Chakraborty Committee (RBI, 1985) recommended the concept of monetised deficit. The monetized deficit is the increase of net RBI credit to the central government (Note 2).

The traditional measure of the budget deficit and its expanded form, the monetised deficit, excludes part of the resource gap of the government, which is financed through borrowing outside RBI. Thus, in recent years, the emphasis has been given to contain the fiscal deficit, which is the net borrowing requirement of the Government. Conventional measurement of fiscal deficit is defined as the difference between total government receipts (non-debt creating) and the total government expenditure net of repayment of previously incurred debt. In India, the gross fiscal deficit is defined as the excess of the total of revenue expenditure, capital outlay and net lending over revenue receipts and non-debt-creating capital receipts including the proceeds from disinvestment. Thus, Gross Fiscal Deficit $=$ Revenue Expenditure + Capital Outlay + Net Lending $-($ Revenue Receipts + Non-debt creating Capital Receipts).

Methodological limitations apart, it should be noted that in India, a reliable measure of total public sector deficit, the ideal measurement of deficit to capture the macroeconomic impacts, is not constructed due to paucity of data on intra-public sector transactions and the data at subnational (local) government. Therefore, the second best alternative measure of the deficit which can capture the macroeconomic impacts in India is the gross fiscal deficit.

Along with fiscal deficit, other important deficit indicators introduced to assess the budgetary performance of the government are primary deficit and revenue deficit. In India, the primary deficit is an indicator to assess the impact of current year's discretionary fiscal action on the indebtedness of the government. Primary Deficit $=$ Fiscal Deficit - Interest payments.

Revenue deficit as a concept has received immense attention in recent years. Boskin (1988) argued that conventional deficit does not measure government dissavings, the latter being reflected in the revenue deficit. Revenue deficit is defined as the difference between the revenue earning of the government and revenue / current expenditure government. In the context of the structural adjustment programme, as a policy of demand management, reduction of both fiscal and primary deficit assumed paramount importance. Among the economists, there have been arguments for and against the adoption of these indicators to evaluate the budgetary performance of the government.

The trends in different concepts of deficits in India as a percent of GDP are given in Figure 1. The trends in deficits revealed that budget deficit and monetized deficit was controlled intertemporally though the latter has shown a rise in the recent years. The revenue deficit is not yet completely phased out in India. The primary deficit and fiscal deficit have moved in tandem and have shown a comparatively slight decline in the recent years, as percent of GDP.

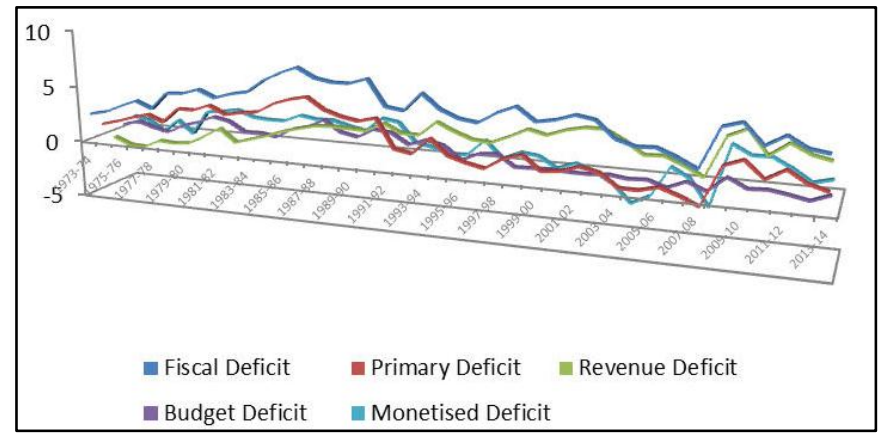

Figure 1. Trends in deficits (as percent of GDP)

Source: (basic data), RBI (various years). 
The fiscal deficit is financed through the issuance of bonds, seigniorage financing, financing through ad-hoc Treasury Bills and external financing. It is evident from figure 2 that over the years, Government of India resorted more to internal financing than to external financing, and market borrowing (bond financing of deficits) has emerged as the most important source of financing of fiscal deficit in India. The rationale behind the market borrowing by the Central Government was to create and widen the investor's base for government securities outside the captive market by attractive rates of interest and thereby to reduce government's dependence on monetisation of deficit.

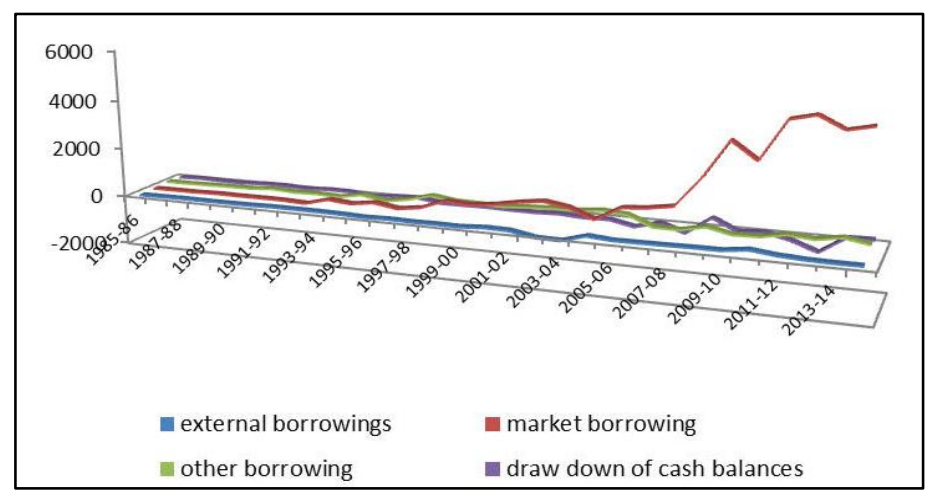

Figure 2. Financing pattern of deficits (in Rs crores)

Source: (basic data), RBI (various years).

The deregulation of interest rate in India made market borrowing more expensive because of the sharp rise in the interest rates on government securities. When government's ability to monetize the fiscal deficit became limited, especially after doing away with automatic monetisation of deficit through ad-hoc Treasury bill in April 1st, 1997, government has been compelled to resort to high cost market borrowing to finance the fiscal deficit. Increasing recourse to bond financing is reflected in the increase in the share of market borrowing during the 1990s (Figure 2).

It is important in this context to understand the role of fiscal policy in creating seigniorage revenue in India. Historically the change in reserve money in India is attributed to the conventional budget deficit of the government or deficit financing (monetisation of fiscal deficit). Ex-post to Chakravarty Committee Report (Reserve Bank of India, 1985), the government has made a clear distinction between the overall budget deficit and deficit financing since their implications on money supply could be entirely different. The overall budget deficit denoted the gap between the expenditure and the receipts under revenue and capital accounts taken together and this budgetary gap was met by the sale of Treasury Bills (of 91-day maturity period). This conventional budget deficit had been phased out since 1997-98. On the other hand, deficit financing refers to the increment during the year on the net RBI credit to the Government (for details, Rakshit, 1993). Through an institutional reform, of signing an agreement between central bank and central government, thus the monetized deficit has been reduced in India.

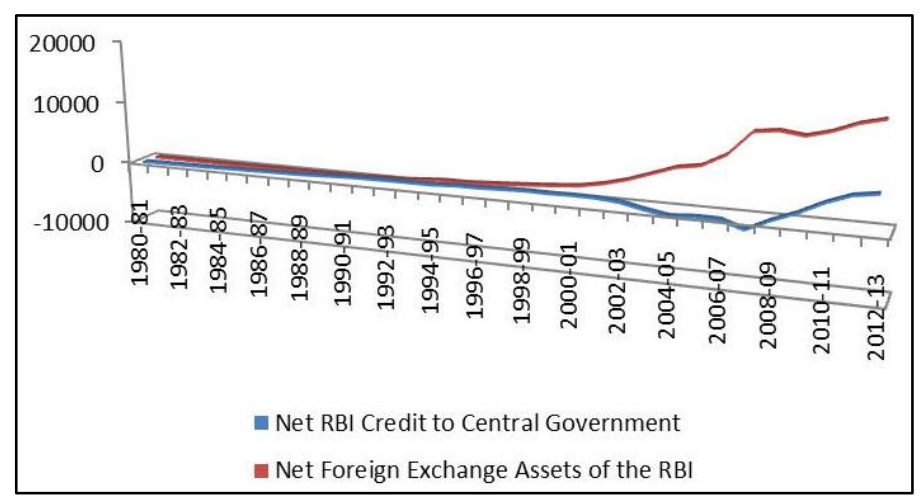

Figure 3. Two significant components of reserve money (in Rs crores)

Source: (basic data), RBI (various years). 
It is evident from Figure 3 that despite controlling for the monetized deficit (net RBI credit to the Government), the reserve money has not been able to decline. The factor which contributed to this trend of no significant decline of reserve money, despite the decline in net RBI credit to the Government, is due to the increasing share of net foreign exchange assets of RBI in reserve money creation (Figure 3). The net RBI credit to the Government is on the increase recently, and it is important to test whether it has implications for seigniorage-deficit linkages.

The second institutional reform was imposing fiscal rules on public deficits in India. A fiscal rule imposes a long-lasting constraint on fiscal policy through numerical limits on budgetary aggregates (Kopits \& Symansky, 1998). This implies that a domain is set for fiscal policy which cannot be frequently changed and a roadmap is provided by specifying a numerical target that limits a particular budgetary aggregate. The Fiscal Rules aim at correcting distorted incentives and containing pressures to overspend, in particular in good times, so as to ensure fiscal responsibility and debt sustainability (Andrea Schaechter et al., 2012).

In India, the "golden rule" is invoked for the reduction of revenue deficit to zero or negative levels. A limit on fiscal deficits to 3-5 per cent of GDP was imposed with an emphatic rationale to avoid "crowding out" of private investment. However, many empirical evidences do not suggest 'direct' or 'financial' crowding out in the context of India (Chakraborty, 2002, 2006, 2007, 2012; Chakraborty \& Chakraborty, 2008; Goyal, 2004; Vinod, Chakraborty, \& Karun, 2014) that deficits crowd out private corporate investment, and does not induce rise in interest rates or output gap either.

What is missing in the design of numeric fiscal rules is the macroeconomic channel through which the deficits affect the output gap. It is not only the levels of deficit, but also the financing pattern of deficits that creates macroeconomic consequences. This aspect was surpassed in the debates related to Fiscal Rules and budget management policies. The Fiscal Rules have taken the deficit financing rules as granted and deal with only numerical targets of deficits. However, excessive use of any financing mode of deficits has macroeconomic repercussions and cannot be tackled by focusing on the fiscal rules alone. Against this backdrop, the construction of seigniorage is attempted in next section.

\section{Estimating Seigniorage}

There was an increasing recognition that the seigniorage causes inflation (Easterly \& Schimdt-Hebbel, 1993; Dornbusch \& Fischer, 1981; Van Wijnbergen, 1989; Buiter, 2007; and Easterly \& Schmidt-Hebbel, 1994). The monetary seigniorage is defined as the change in the nominal stock of reserve money (Buiter, 2007). It is measure of seigniorage which is a change in reserve money divided by GDP at current prices.

Monetary seigniorage can be expressed by the following equation:

$$
S_{1}=\frac{\Delta M_{t}}{Y_{t}}
$$

Where $\mathrm{S}_{1}=$ seigniorage revenue;

$\Delta \mathrm{M}_{\mathrm{t}}=$ change in reserve money; and

$\mathrm{Y}_{\mathrm{t}}=\mathrm{GDP}$ at current prices.

Equation (6) can be rewritten in the following form

$$
\begin{gathered}
S_{r e v}=\frac{\Delta M_{t}}{M_{t}} * \frac{M_{t}}{Y_{t}} \\
S_{r e v}=\mu_{t} * m_{t}
\end{gathered}
$$

Where, $\mu_{t}=\Delta M_{t} / M_{t}$ and $m_{t}=M_{t} / Y_{t}$.

As per equation (2), seigniorage is defined as the product of the rate of growth of nominal reserve money $\left(\mu_{t}\right)$ and the reserve money per unit of GDP $\left(m_{t}\right)$.

A distinct but related concept of revenue from Central Bank and seigniorage is inflation tax. Inflation tax and seigniorage are not synonymous always. Inflation tax is the erosion of the value of reserve money held by the public.

Seigniorage (S2) can be decomposed further into two components: inflation tax and real change in the reserve money. The change in reserve money in real term can be written as

$$
S_{2}=\frac{M_{t}-M_{t-1}}{P_{t}}
$$




$$
\begin{gathered}
S_{2}=\frac{M_{t}}{P_{t}}-\frac{M_{t-1}}{P_{t}}+\frac{M_{t-1}}{P_{t-1}}-\frac{M_{t-1}}{P_{t-1}} \\
S_{2}=\frac{M_{t}}{P_{t}}+\left(M_{t-1} * \frac{\pi_{t}}{P_{t}}\right)-\frac{M_{t-1}}{P_{t-1}} \\
S_{2}=\dot{m}_{t}+\pi_{t} * m_{t-1}
\end{gathered}
$$

where $\pi_{t}=\frac{\left(P_{t}-P_{t-1}\right)}{P_{t-1}}, \quad \dot{m}_{t}=\frac{M_{t}}{P_{t}}-\frac{M_{t-1}}{P_{t-1}}, \quad m_{t-1}=\frac{M_{t-1}}{P_{t}}$.

The equation (3) expresses seigniorage as the sum of increase in the real stock of money $m$ and the change in real stock of money that would have occurred with a constant nominal stock because of inflation $(\pi \mathrm{t} *$ mt -1$)($ Agenor $\&$ Montiel, 1996). The expression ( $\pi \mathrm{t} * \mathrm{mt}-1)$ of equation (8) is the inflation tax.

As mentioned above, the inflation tax is not always equal to seigniorage. They are equal only in a stationary state, that is, when mt becomes zero. From equation (3), it becomes clear that inflation tax revenue is a component of seigniorage revenue. The inflation tax, as noted above, is the product of inflation rate (tax rate) and the real monetary base (tax base).

$$
I_{\text {tax }}=\pi_{t} * m_{t-1}
$$

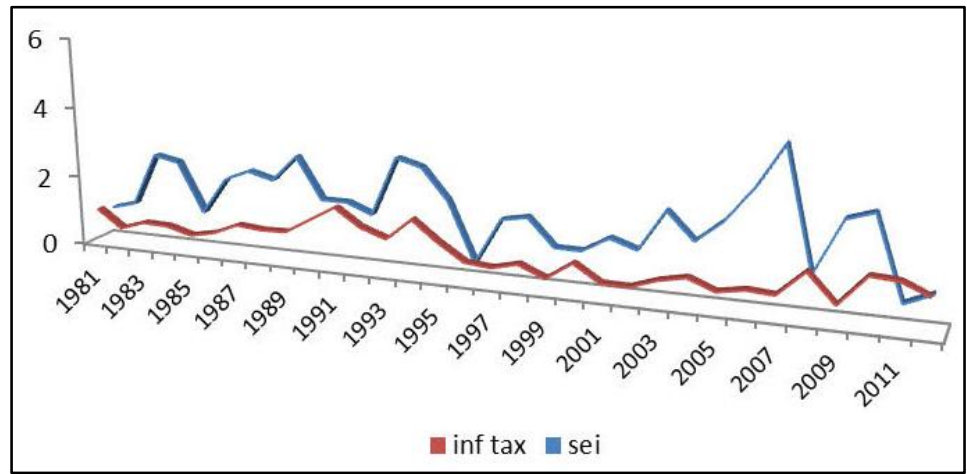

Figure 4. Monetary Seigniorage and inflation tax (as percent of GDP)

Source: (basic data), RBI (various years).

Seigniorage and Inflation tax are equal only in a stationary state. In other words, seigniorage is defined as the change in high-powered money to GDP while inflation tax is defined as the product of the rate of inflation and high-powered money in period (t-1). Figure 4 presents the trends in illustrative estimates of seigniorage and inflation tax for India; the trend revealed that the former (seigniorage generation) has not crossed over 4 percent of GDP. It can be seen from the figure 4 that there have been wide year-to-year fluctuations in the creation of seigniorage in India during the last three decades.

\section{Estimating Seigniorage Laffer Curve}

Sargent and Wallace (1981) and Bruno and Fischer (1990) noted that there might be both high and low inflation equilibrium when government finances the deficit through seigniorage. The dual equilibria - a reflection of Laffer curve - imply that an economy may be stuck in high inflation equilibrium when, with same fiscal deficit as percent of GDP, it could be at a lower inflation rate. The Seigniorage Laffer curve phenomenon depicts the non-linear relationship between revenue from money creation $\left(\mu_{t}\right)$ and the inflation rate $\left(\pi_{t}\right)$. Easterly et al. (1994) noted that econometric estimation of the following quadratic equation statistically confirms the seigniorage Laffer curve.

$$
S_{\text {rev }}=\alpha+\beta_{1} \pi_{t}+\beta_{2} \pi^{2}{ }_{t}+v_{t}
$$

where Srev is seigniorage and $\pi \mathrm{t}$ is the rate of inflation.

The monetary seigniorage is estimated using two data sets; high frequency data (monthly) for the period ex-post to global financial crisis and also using the annual data for the period 1970-71 to 2012-13. However the high 
frequency data estimation of fiscal seigniorage is not possible as the data on public expenditure on interest payments is not available on monthly basis. One way to tackle this problem partially is to deduct the bond market operations data from the fiscal deficit. The analysis is thwarted here too as the high frequency data on bond financing of deficit is not available, though fiscal deficit could be available for the recent decade on monthly basis.

Using error correction mechanism, the plausibility of monetary seigniorage Laffer curve estimated using the high frequency data, 2009:03 to 2013:07, for India is reported in Table 1. The estimation revealed that monetary seigniorage Laffer curve exists in the context of India, ex-post to global financial crisis period. The squared coefficient is negative and significant, which depicted that the seigniorage revenue creation initially rises and eventually falls with the rise in the rate of inflation, the estimates ( $\pi$ and $\Pi 2)$ are significant (Table 1 ).

Table 1. High frequency data estimation of monetary Seigniorage Laffer Curve: ECM estimates for 2009:03 to 2013:07

\begin{tabular}{ccc}
\hline & coefficient & t \\
\hline $\boldsymbol{\alpha}$ & -0.094 & -0.653 \\
$\pi$ & & {$[0.516]$} \\
& 1.078 & 1.638 \\
$\boldsymbol{\Pi}^{2}$ & & {$[0.108]$} \\
& $-0.095^{*}$ & -1.739 \\
$\mathbf{e c m}$ & & {$[0.088]$} \\
R-squared & $-0.645^{* * *}$ & -11.545 \\
\hline
\end{tabular}

Note. figures in the parentheses denote probability.

Source: (Basic data), RBI (various years).

Theoretically, the coefficient of $\Pi^{2}$ provides a seigniorage-maximising inflation rate, which provides the plausible inflation rate where the seigniorage Laffer curve peaks. This model can be extended by incorporating the relevant control variables and the policy dummy to capture the phasing out of monetized deficits in 1997. However, these results are partial and illustrative.

Table 2. Annual frequency data estimation of monetary Seigniorage laffer curve: error correction mechanism estimates for 1970-71 to 2012-13

\begin{tabular}{cccc}
\hline Variable & Coefficient & t-Statistic & Prob. \\
\hline $\boldsymbol{\alpha}$ & -0.020 & -0.217 & 0.829 \\
$\boldsymbol{\pi}$ & $1.932^{* * *}$ & 4.614 & 0.0001 \\
$\boldsymbol{\Pi}^{\mathbf{2}}$ & $-0.500^{*}$ & -3.118 & 0.004 \\
$\mathbf{E C M}$ & $-0.833^{* * *}$ & -7.087 & 0.000 \\
$\mathbf{R}$-squared & 0.423 & & \\
\hline
\end{tabular}

Source: (Basic data), RBI (various years).

The re-specification of the nonlinear monetary seigniorage Laffer curve models with annual frequency data is reported in Table 2. The model provided a preliminary evidence for the seigniorage Laffer curve.

The seigniorage maximizing inflation rate from these preliminary estimations are seemingly not explosive rates and there could be a possibility for seigniorage financing at moderate inflation rates. However, these estimates are illustrative and needs to be read with caution, and these non-linear models need to be further strengthened by incorporating appropriate control variables. These preliminary estimates have policy implications on the current mode of financing public deficits in India, with bond financing as the predominant method. It is interesting to recall heterodox economists' emphasis to seigniorage finance of deficits for public deficits, as they believe it is in technical terms "free lunch", if the economy has not attained the full employment levels (for details, Rakshit, 2005, 2010).

If we take recourse to the original arguments for monetary-fiscal linkages, bond financing of deficits can be flawed even under a fiscal dominance regime. Does bond financing - the dominant source of financing the deficit in India - has an empirical upper bound? If so, does it imply when the rate of interest on government bonds exceed the growth rate of the economy, we need to monetize eventually the deficits through generating 
seigniorage? The fiscal stance, however, would not be unsustainable soon in India, as the present structure of deficit financing has a negligible share of external financing of debt, and the composition of debt is more of long term maturities. Still, the assumption that the monetary regime has no influence on the conduct of fiscal policy need a revisit, especially when the economic growth rate $(\mathrm{g})$ is plummeting and the rates of interest (r) have shown no signs for a significant downward trend in recent years in India. This concern is not because of any straightjacket unsustainability condition of $r>g$ impending for India, but the monetary policy stance contains relevance for the term structure of interest rates (the relationship between short and long-term rates of interest) and has a catalytic role in promoting economic growth.

\section{Conclusion}

There is a growing recognition to analyse the fiscal monetary policy co-ordination while assessing the efficacy of public deficits on economic outcomes. However, the tendency to dichotomize the monetary and fiscal policy is attaining strength over time, with macroeconomic policy transition from discretion to rules. Against this backdrop, my paper analysed the contemporary macroeconomic policy in India and explored the plausible policy co-ordination between central bank and fiscal authorities through estimating the monetary seigniorage.

The genesis of such analysis can be traced back to "Unpleasant Monetary Arithmetic" of Sargent and Wallace (1981), later reappeared as the "fiscal theory of the price level", (FTPL), pioneered by Leeper (1991), Sims (1994), Woodford (1994) and Cochrane, J H (1998). Under these theoretical constructs, it was concluded that if the rate of interest ( $r$ ) moves above the rate of growth of economy $(\mathrm{g}), \mathrm{r}>\mathrm{g}$, debts and deficits become sooner or later unsustainable, and the Central Bank has to step in and generate the monetary seigniorage revenues to monetize the deficits eventually.

The price level in FTPL is independent of monetary policy but dependent strictly on fiscal policy; price level indeterminacy problems can be solved by having the central bank peg the nominal interest rate at a level consistent with the central bank's desired inflation rate, rather than by controlling the growth rate of the (base) money supply (Sims, 1994; Woodford, 1994).

With the test of theories, we identified that despite the concerted policy changes undertaken by the Government of India and the Central Bank to contain the monetized deficit in India, the monetary seigniorage is not yet on the decline. Though the net RBI credit to the government (monetized deficit) has been controlled through policy co-ordination, the net FOREX reserve is on the rise. Further, the shift in the financing pattern of deficits from seigniorage to bond financing which has occurred prior to the deregulation of interest rate regime in India has implications for the monetary seigniorage.

Of late, the monetary policy authorities have begun the policy rules towards 'inflation targeting' and 'central bank independence' in India. Consequently, the coordination between fiscal and monetary policy has weakened and fiscal rules were implemented with numeric values of deficits -the 'levels' of deficit to 3 percent of GDP. A widening acceptance has become reality over the years that numeric Fiscal Rules are associated with greater fiscal responsibility. The paper examines such theoretical and empirical linkages between fiscal and monetary policy through seigniorage Laffer curve.

The estimates of monetary Seigniorage Laffer curve using error correction mechanism models suggested the possibility of a Seigniorage Laffer curve phenomenon in India. These estimations are partial and illustrative. The plausibility of existence of seigniorage Laffer curve opens the possibilities of monetary and fiscal policy co-ordination, especially when India is moving towards central bank independence and new monetary policy framework. More research is required to estimate the "fiscal seigniorage" as estimated by Neumann (which is beyond the scope of present paper. Fiscal seigniorage, a wider concept than traditional monetary seigniorage to take into consideration the institutional and policy changes which has direct bearing on government's net monetary finance requirement, can be a plausible extension of this paper.

The policy implication for my results is the relevance of macroeconomic policy co-ordination between fiscal and monetary authorities. The situation of central bank independence and inflation targeting with no fiscal policy dominance -Unpleasant Fiscal Arithmetic - can have adverse macroeconomic consequences. The reversal of order of transition of the first mover advantage from fiscal agencies to the Central Bank authorities can result in macroeconomic uncertainties. Equally important is that the fiscal policy rules should not lead to such a situation where fiscal agencies obliges to adjust to the anti-inflationary policy of the independent Central Bank.

\section{Acknowledgements}

Special thanks are due to Pinaki Chakraborty for the valuable comments. Thanks are also due to Samreen Badr and Kavita Issar for their technical inputs in preparing the paper. 


\section{References}

Agenor, R. P., \& Montiel, P. J. (1996). Development Macroeconomics. Princeton: Princeton University Press.

Alesina, A., \& Perotti, R. (1995). The Political Economy of Budget Deficits. IMF Staff Papers, 42, 1-31. https://doi.org/10.2307/3867338

Blejer, M., \& Adrienne, C. (1993). How to Measure the Fiscal Deficit. Washington, DC: International Monetary Fund.

Blejer, M., \& Chu, K. Y. (1988). Measurement of Fiscal Impact: Methodological Issues. IMF Occasional Paper No. 59, Washington, DC: International Monetary Fund.

Blinder, A. S., \& Solow, R. (1974). Analytical Foundations of Fiscal Policy. In A. S Blinder et al. (Eds.), The Economics of Public Finance. Washington: Brookings Institution.

Boskin, M. J. (1988). Concepts and Measures of Federal Deficits and Debt and Their Impact on Economic Activity. In K. J. Arrow, \& M. J. Boskin (Eds.), The Economics of Public Debt, St. New York: Martin Press. https://doi.org/10.1007/978-1-349-19459-9_3

Bruno, M., \& Fischer, S. (1990). Seigniorage, Operating Rules and the High Inflation Trap. Quarterly Journal of Economics, 105, 353-74. https://doi.org/10.2307/2937791

Buiter, W. (2007). Seigniorage. NBER Working Paper No. 12919, NBER.

Cagan, P. (1956). The Monetary Dynamics of Hyperinflation. In M. Friedman (Ed.), Studies in the Quantity Theory of Money. Chicago: University of Chicago Press. PMid:13305424

Cagan, P. (1972). The Channel of Monetary Effects on Interest Rates. NBER, No. 97, General Series, London: Columbia University Press.

Chakraborty, P., \& Lekha, C. (2008). Is Fiscal Policy Contra cyclical in India: An Empirical Analysis (co-authored). Policy Innovations, New York: The Carnegie Council. Also published as MPRA Working Paper No. 7604, Munich: Munich Personal Repec Archive.

Cochrane, J. H. (1998). What Do the VARs Mean? Measuring the Output Effects of Monetary Policy. Journal of Monetary Economics, 41(2), 277-300. https://doi.org/10.1016/S0304-3932(97)00075-5

Dornbusch, R., \& Fischer, S. (1981). Budget Deficits and Inflation. In J. Flanders, \& Razin (Eds.), A Development in an Inflationary World. New York: Academic Press.

Easterly, W., \& Schimdt-Hebbel, K. (1993). Fiscal Deficits and Macroeconomic Performance in Developing Countries. The World Bank Research Observer, 8(2), 211-37. https://doi.org/10.1093/wbro/8.2.211

Easterly, W., Rodriguez, A., \& Schmidt-Hebbel, K. (1994). Public Sector Deficits and Macroeconomic Performance. Oxford, New York: Oxford University Press.

Goyal. (2004). Does Higher Fiscal Deficit Lead to Rise in Interest Rates? Economic and Political Weekly, 39(21). (Mumbai).

Heller, P., Richard, H., \& Ahsan, S. M. (1986). A Review of the Fiscal Impulse Measure. IMF Occasional Paper No 44, Washington DC.

Jean-Louis, C., Xavier, D., Alexandru, M., \& Reé, T. (2014). Inflation Targeting and Fiscal Rules: Do Interactions and Sequencing Matter? IMF Working Paper No. 89, Washington DC.

Klein, M., \& Manfred, J. M. N. (1990). Seigniorage: What is It and Who Gets It? Weltwirtschaftliches Archiv, (Heft 2/1990), 205-21.

Kopits, G., \& Symansky, S. (1998). Fiscal policy rules. IMF Occasional Paper No.162, Washington DC.

Leeper, E. M. (1991). Equilibria Under Active and Passive Monetary and Fiscal Policies. Journal of Monetary Economics, 27, 129-47. https://doi.org/10.1016/0304-3932(91)90007-B

Lekha, C. (2002). Fiscal Deficit and Rate of Interest Link in India: An Econometric Analysis of Deregulated Financial Regime. Economic and Political Weekly, 37(19).

Lekha, C. (2006). Fiscal Deficit and Selected Rates of Interest Link in India: An Analysis of Period between 1970-71 and 1999-2000. In D. K. Srivastava, \& M. Narasimhulu (Eds.), State Level Fiscal Reforms in the Indian Economy (Vol. 1). New Delhi: Deep and Deep.

Lekha, C. (2007). Fiscal Deficit, Capital Formation and Crowding Out: Evidence from Asymmetric VAR Modeling. Working Paper No. 43, New Delhi: National Institute of Public Finance and Policy, and Working 
Paper No. 518, Annandale-on-Hudson, NY: Levy Economics Institute of Bard College.

Lekha, C. (2012). Interest Rate Determination in India: Empirical Evidence from fiscal deficit rate of interest linkages and Financial Crowding Out. Working Paper No. 110. New Delhi: National Institute of Public Finance and Policy, and also published as Working Paper No. 731, Annandale-on-Hudson, NY: Levy Economics Institute of Bard College.

Neumann, M. (1992). Seigniorage in the United How Much Does the U. S. Government Make from Money Production? Research Paper, Federal Reserve Bank of St. Louis, USA.

Pattnaik, R. K., Pillai, S. M., \& Das, S. (1999). Budget Deficit in India: A Primer on Measurement. Department of Economic Analysis and Policy, Mumbai: RBI Staff Studies.

Rakshit, M. (1993). Money, Credit and Monetary Policy. In T. Majumdar (Ed.), Nature, Man and the Indian Economy. Oxford; New York and Toronto: Oxford University Press.

Rakshit, M. (2005). Budget Deficit: Sustainability, Solvency, and Optimality. In A Bagchi Readings in Public Finance. New Delhi: Oxford University Press.

Rakshit, M. (2010). Fiscal Consolidation and Inclusive Growth: The Finance Commission Approach, in Special Edition on Thirteenth Finance Commission. In C. Pinaki (Ed.), Economic and Political Weekly (Vol. 45, No. $48)$.

RBI. (1985). Committee to Review the Working of the Monetary System (Sukhamoy Chakravarty report). Mumbai: Reserve Bank of India.

RBI. (2012). The Report of Currency and Finance. Mumbai: Reserve Bank of India.

RBI. (2014). The report of the Expert Committee to revise and strengthen the monetary policy framework (Urjit Patel report). Mumbai: Reserve Bank of India.

RBI. (various years). Handbook of Statistics of Indian Economy. Mumbai: Reserve Bank of India.

Sargent, T. J., \& Wallace, N. (1981). Some Unpleasant Monetary Arithmetic. Federal Reserve Bank of Minneapolis Quarterly Review.

Schaechter, A., Tidiane, K., Nina, B., \& Anke, W. (2012). Fiscal Rules in Response to the Crisis-Toward the "Next-Generation" Rules A New Dataset. Working Paper No. 187, International Monetary Fund.

Sims, C. (1994). A simple model for the study of the determination of the price level and the interaction of monetary and fiscal policy. Economic Theory, 4, 381-99. https://doi.org/10.1007/BF01215378

Taylor, J. B., \& John, C. W. (2010). Simple and Robust Rules for Monetary Policy. In B. M. Friedman, \& M. Woodford (Eds.), Handbook of Monetary Economics (Ch. 15, 1st ed., Vol. 3, pp. 829-59). Elsevier. https://doi.org/10.3386/w15908

Van Wijnbergen, S. (1989). Cash Debt Buybacks and the Insurance Value of Reserves. Policy Research Working Paper Series 256, The World Bank.

Vinod, H. D., Lekha, C., \& Honey, K. (2014). If deficit, not the culprit, what determines interest rate in India: Evidence from Maximum Entropy Bootstrap for Time Series. Working Paper No. 567. Annandale-on-Hudson, NY: Levy Economics Institute of Bard College.

Woodford, M. (1994). Monetary Policy and Price Level Determinacy in a Cash-Advance Economy. Economic Theory, 4, 345-80. https://doi.org/10.1007/BF01215377

\section{Notes}

Note 1. For details on fiscal-monetary policy co-ordination, see Reserve Bank of India, 2012.

Note 2. RBI's holding of ad hocs, dated government securities, 91 days Treasury bills and government's currency liabilities constitute the net RBI credit central government, the measure of monetised deficit in India.

\section{Copyrights}

Copyright for this article is retained by the author(s), with first publication rights granted to the journal.

This is an open-access article distributed under the terms and conditions of the Creative Commons Attribution license (http://creativecommons.org/licenses/by/4.0/). 